\title{
Middle Pleistocene interglacial deposits near Herning, Jylland, Denmark
}

\author{
Bent V. Odgaard, Karen L. Knudsen, Ole Bennike and Henrik J. Granat
}

Marine interglacial deposits are fairly common and widespread in Denmark, but so far none have been reported from the Herning area in central Jylland. In 2014, the Geological Survey of Denmark and Greenland (GEUS) received samples at one metre intervals from a borehole at $55^{\circ} 59.3^{\prime} \mathrm{N}, 8^{\circ} 56.6^{\prime} \mathrm{E}$ (elevation $27.56 \mathrm{~m}$ above sea level), at Hesselvigvej 7 near Kibæk in central Jylland (Fig. 1). The succession consisted of Miocene and Quaternary deposits. The Quaternary part was dominated by glaciofluvial sand and a single till bed, but it also contained a marine clay unit (16-21 $\mathrm{m}$ depth, 6.5-11.5 $\mathrm{m}$ a.s.l.). This marine clay con- tained spines of the sea-urchin Echinocardium cordatum, a boreal species known from Eemian and Holocene deposits from Denmark, but unknown from interstadial deposits. A lacustrine unit between 26 and $33 \mathrm{~m}$ depth $(5.5 \mathrm{~m}$ b.s.l. to $1.5 \mathrm{~m}$ a.s.l.) consisted of clay, calcareous-rich gyttja and diatomite. Because Quaternary marine deposits are unexpected in this part of Denmark, we report here on analyses of pollen from the lacustrine unit and foraminifera from the marine unit, and we compare these with some interglacial records from Jylland. The analysed samples were treated with standard laboratory methods.
Fig. 1. A: Map of Denmark showing the location of the Herning area (red rectangle) and selected interglacial sites. 1: Harboøre (DGU 43.75), 2: Kås Hoved (DGU 45.759), 3: Holstebro Nord (DGU 64.248), 4: Hoven (DGU 103.1011), 5: Vorbasse (DGU 123.1217). B: Map of the Herning area showing interglacial sites. C: Simplified lithological log of the core at Kibæk (DGU 95.2875), with two interglacial units.
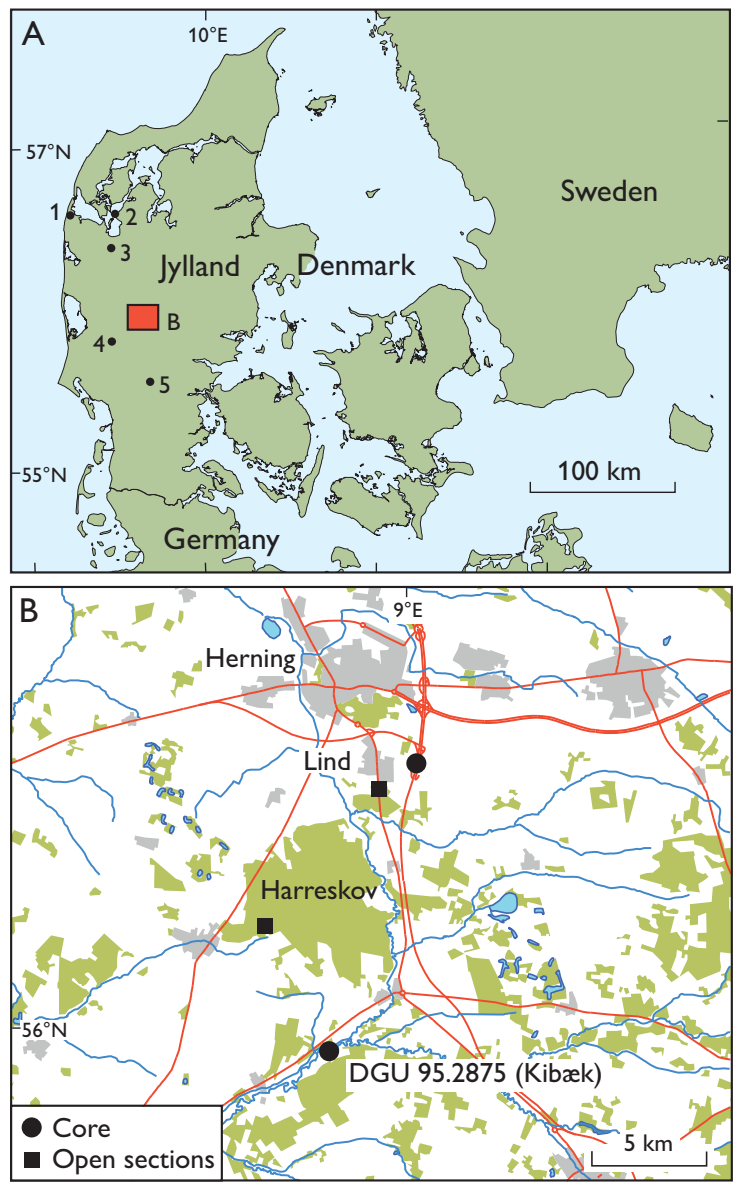

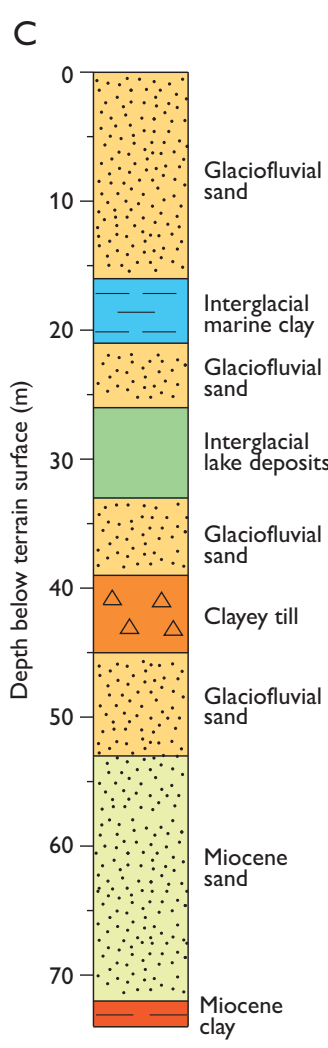




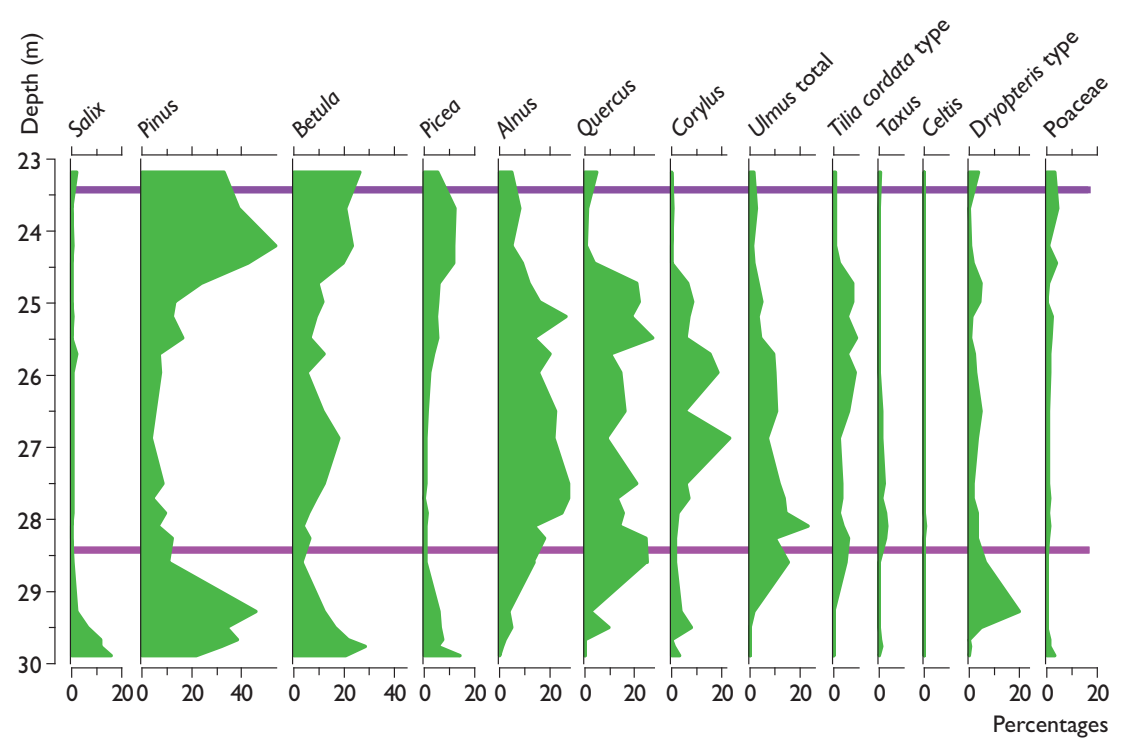

Fig. 2. Simplified percentage pollen diagram from the interglacial deposit at Lind with indication of the stratigraphical correlation of the two pollen samples from Kibæk (DGU 95.2875; purple lines).

\section{The lacustrine unit}

Pollen data from two samples (at 31 and $30 \mathrm{~m}$ depth) from the organic lacustrine (gyttja) unit clearly show that this is an interglacial deposit with thermophilous taxa such as Tilia (lime) and Buxus (box). The lack of Carpinus (hornbeam) is noteworthy and makes a correlation with the Holstenian or Eemian periods unlikely. In 2003 a core was secured through a thick interglacial deposit at nearby Lind, $14 \mathrm{~km}$ north of the Kibæk borehole (Kronborg \& Odgaard 2004; Fig. 1). The pollen record of the interglacial part of the Lind core shows a clear correlation to the Harreskovian (Andersen 1965), with absence of Carpinus, presence of Picea (spruce) throughout the series and traces of Celtis (hackberry; Fig. 2). An ordination (principal component analysis, PCA) on the Lind interglacial pollen samples with the Kibæk pollen spectra as supplementary samples shows that the bottom Kibæk sample correlates well with a level of $28.4 \mathrm{~m}$ of the Lind core and the upper Kibæk sample with Lind at $23.4 \mathrm{~m}$ (Figs 2,3). This indicates that a full, but thin interglacial lacustrine succession is present at Kibæk. The reason for the thin succession could be that the core site is located near the margin of the former lake basin.

\section{The marine unit}

The foraminiferal assemblages from the marine unit (Fig. 4) are dominated by Elphidium excavatum, with Ammonia beccarii second in abundance. The species composition indicates subtidal, inner-shelf conditions with a gradual shallowing of the water depth and deposition during a full interglacial period. The species Ammonia beccarii currently has a northern geographical range limit along southern Norway, and it is not present in interstadial deposits such as the Bølling and Allerød in Denmark. Ammonia beccarii immigrated with the marine transgression in the early Holocene.

A principal component analysis (PCA) on selected interglacial foraminiferal stratigraphies from central and north-

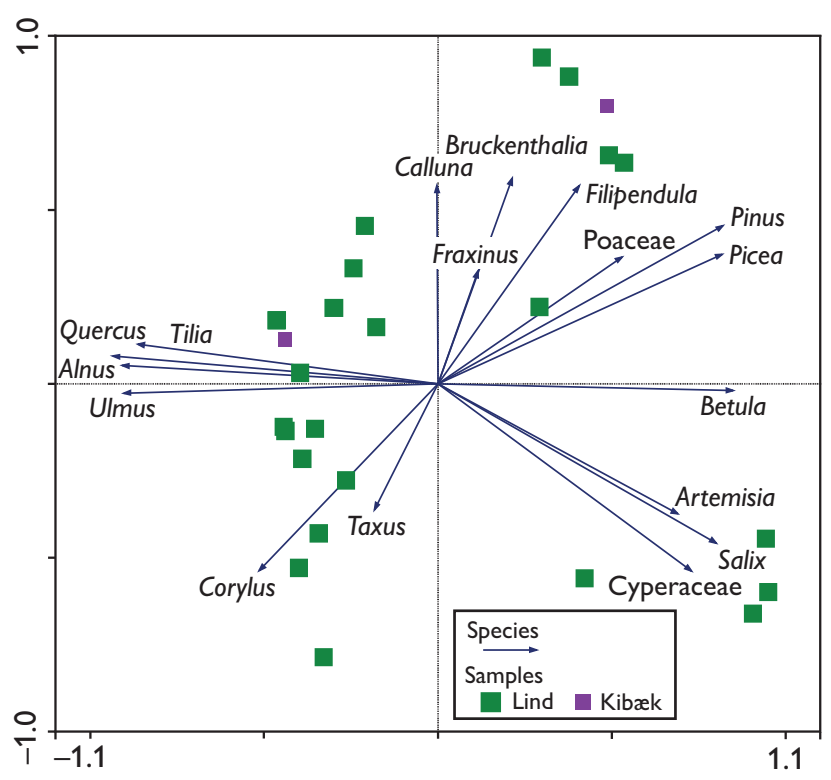

Fig. 3. Principal component analysis (PCA) biplot of the interglacial pollen sequence of Lind with the two Kibæk samples as supplementary samples not influencing the geometry of the plot. The percentage values were log-ratio transformed prior to the analysis. PCA is an ordination technique, which reduces a multidimensional space (here of pollen types) with associated frequencies to fewer dimensions (PCA axes) in such a way that the new dimensions are determined by the directions of largest variation in the original data set. The technique also allows easy comparison between samples of multivariate data such as those derived from microfossil analysis. 
Fig. 4. Percentage distribution of selected foraminifera in the marine unit of the Kibæk core (DGU 95.2875). Note the different scales.

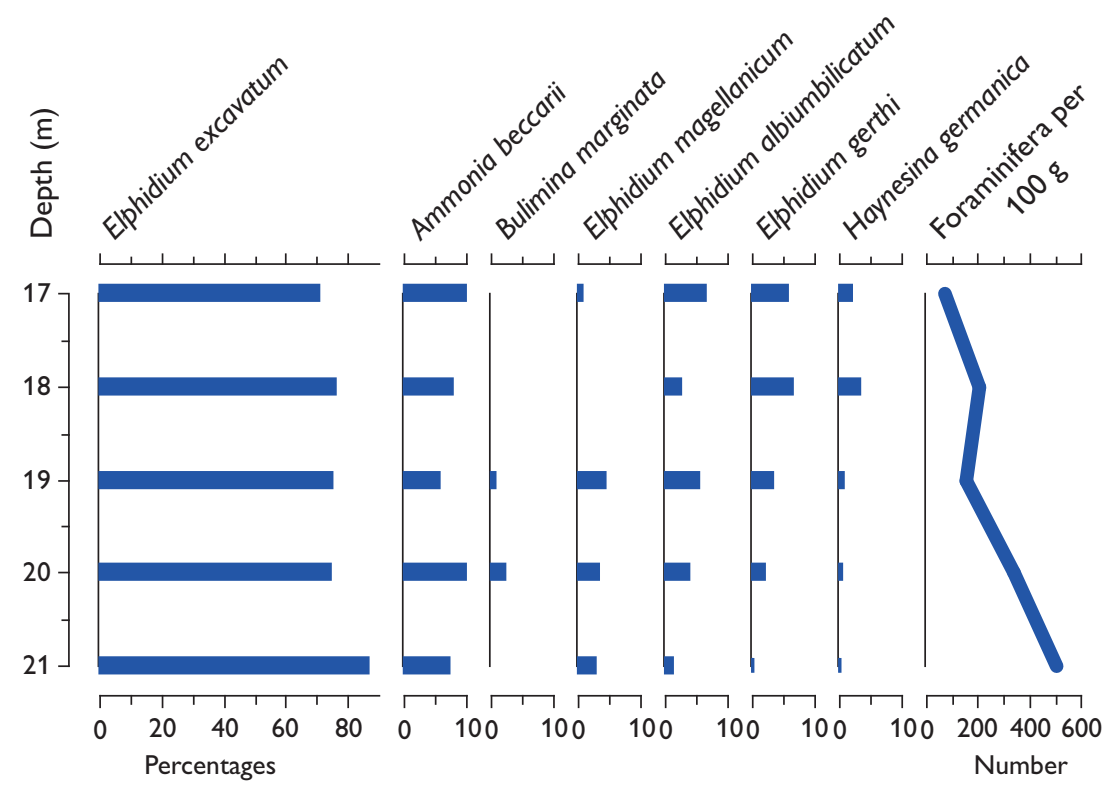

western Jylland shows the Kibæk samples to be intermediate between two long records from Kås Hoved and Holstebro (Fig. 5). This position probably reflects an intermediate facies of the Kibæk deposit between the relatively shallow Kås Hoved facies with Haynesina orbiculare as an important species, and the more open marine environment at Holstebro with Elphidium margaritaceum as one of the indicators of relatively high salinity. The Kibæk foraminiferal assemblages are closely similar to two samples from Harboøre and Vorbasse, and the species composition found in a sample from an additional nearby interglacial deposit at Hoven (Fig. 1; semi-quantitative data) is also very close to those from Kibæk. Elphidium excavatum is dominant and Ammonia beccarii is common in all the comparative records.

\section{Age estimate}

The unusual presence of a lacustrine, as well as a marine sequence in one Pleistocene series provides a minimum age of the bottom till and a maximum age of the marine deposit. The Danish Harreskovian interglacial pollen record can be correlated to the record at Hunteburg in Germany (Hahne et al. 1994). A palaeomagnetic reversal at the base of the Hunteburg series may indicate the presence of the Brunhes-Matuyama boundary, in which case the Hunteburg interglacial series would correspond to marine isotope stage (MIS) 19, almost $800 \mathrm{ka} \mathrm{BP}$. The till at 39-45 m depth at Kibæk would then belong to one of the till units identified in the lower part of the Lind core (Kronborg \& Odgaard 2004), deposited during one of the oldest Pleistocene glaciations recorded from Denmark.
The marine unit represents a full interglacial period, but it was not possible to relate it to a specific interglacial. The deposit is, however, older that the Eemian interglacial (MIS 5e), because of the lack of lusitanian elements that char-

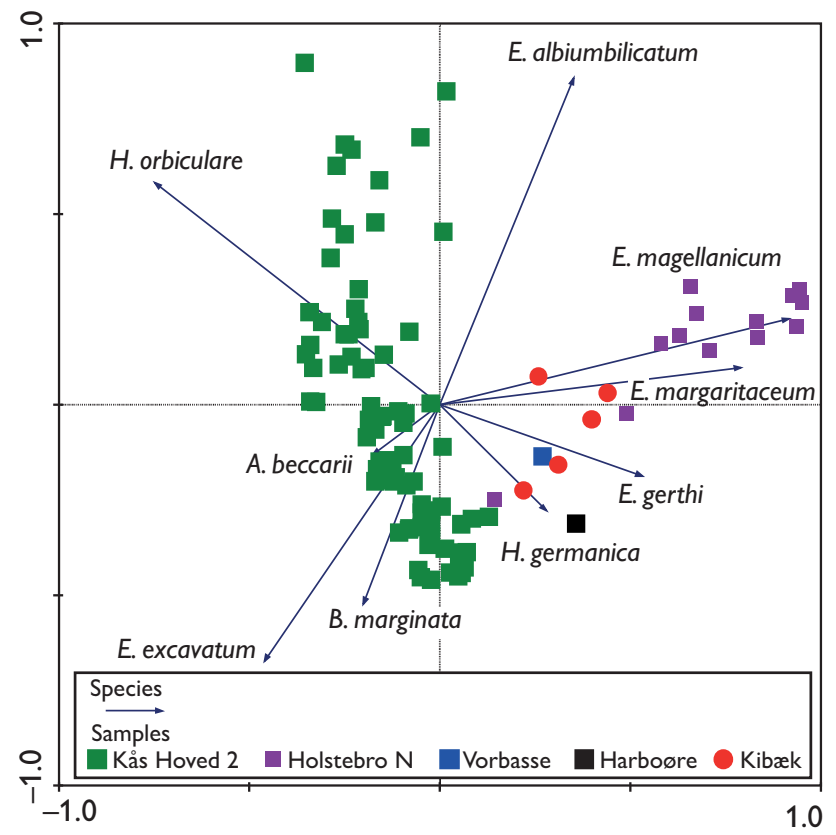

Fig 5. Principal component analysis (PCA) biplot of foraminiferal assemblages from Kås Hoved (Knudsen et al. 2014), Holstebro Nord (Kronborg et al. 2002), Harboøre (Knudsen 1987), Vorbasse (K.L. Knudsen, unpublished data), and Kibæk (this study). A similar assemblage was also found in a sample from a core near Hoven (DGU 103.1011; semiquantitative data in GEUS’ Jupiter database). For locations see Fig. 1. The percentage values were log-ratio transformed prior to the analysis. 
acterise Eemian assemblages in Denmark (e.g. Knudsen 1994). The assemblages from the marine unit are close to those related to Holsteinian interglacial (MIS 11) deposits in Denmark (Fig. 4), but the actual ages of these deposits are also uncertain. A stratigraphical correlation of the interglacial sediments at Kås Hoved with MIS 11 was discussed by Knudsen et al. (2014), but further development of optically stimulated luminescence (OSL) dating or other absolute dating methods are needed for more exact age estimates of marine pre-Eemian interglacial records in Denmark. During the late Early and the Middle Pleistocene, foraminiferal assemblages would be expected to be almost identical during similar marine environmental conditions. Some of the Danish records that are traditionally related to the Holsteinian, could thus be from any warm interglacial period with high sea-level during the late Early or Middle Pleistocene. The stratigraphical position of the marine unit in the Kibæk core indicates a Middle Pleistocene age.

It has been suggested that MIS 11 was an exceptionally long and relatively warm interglacial (e.g. Candy et al. 2014) and peak global sea level may have reached 8.0-11.5 $\mathrm{m}$ higher than today (Chen et al. 2014). However, most temperature proxies for MIS 11 give values similar to the Holocene (Candy et al. 2014), and according to Bowen (2010) sea levels were close to the present sea level. Because of the orbital similarity between MIS 11 and MIS 1, these are even used as analogues of warm intervals in climatic studies (Berger \& Loutre 2003). The temperature indication of interglacial foraminiferal assemblages in Denmark, which is related to the Holsteinian, is also comparable with the Holocene and present day temperatures in the region.

It is remarkable that the Middle Pleistocene marine interglacial records at Kibæk, Vorbasse and Hoven in central Jylland are found several metres above sea level, whereas the Harboøre and Holstebro records in north-western Jylland are found at more than $30 \mathrm{~m}$ b.s.l. A comparison of the core sites with the pre-Quaternary surface map of Denmark (Binzer \& Stockmarr 1994) shows that Kibæk, Vorbasse and Hoven are located in areas with a high-lying pre-Quaternary surface, whereas Harboøre and Holstebro represent an area with a low-lying pre-Quaternary surface. Although glacial tectonics may have displaced some of the interglacial marine records the general elevational pattern of these sediments indicates that the central part of Jylland may have experienced a tectonic uplift during the Quaternary.

\section{References}

Andersen, S.T. 1965: Interglacialer og interstadialer i Danmarks kvartær. Meddelelser fra Dansk Geologisk Forening 15, 486-506.

Berger, A. \& Loutre, M.-F. 2003: Climate 400,000 years ago, a key to the future? American Geophysical Union Geophysical Monograph 137, 17-26.

Binzer, K. \& Stockmarr, J. 1994: Geologisk kort over Danmark. 1:500 000. Prækvartæroverfladens højdeforhold. Danmarks Geologiske Undersøgelse Kortserie 44.

Bowen, D.Q. 2010: Sea level -400000 years ago (MIS 11): analogue for present and future sea level? Climate of the Past 6, 19-29.

Candy, I., Schreve, D.C., Sherriff, J \& Tye, G.J. 2014: Marine Isotope Stage 11: palaeoclimate, palaeoenvironments and its role as an analogue for the current interglacial. Earth-Science Reviews 128, 18-51.

Chen, F., Friedman, S., Gertler, C.G., Looney, J., O'Connell, N., Sierks, K. \& Mitrovica, J.X. 2014: Refining estimates of polar ice volumes during the MIS 11 interglacial using sea level records from South Africa. Journal of Climate 27, 8740-8746.

Hahne, J., Mengeling, H., Merkt, J. \& Gramann, F. 1994: Die Hunteburg-Warmzeit ("Cromer-Komplex") und Ablagerungen der Elster-, Saale- und Weichsel-Kaltzeit in der Forschungsbohrung Hunteburg GE 58 bei Osnabrück. Geologisches Jahrbuch A134, 117-166.

Knudsen, K.L. 1987: Elsterian-Holsteinian foraminiferal stratigraphy in the North Jutland and Kattegat areas, Denmark. Boreas 16, 359368.

Knudsen, K.L. 1994: The marine Quaternary in Denmark: a review of new evidence from glacial-interglacial studies. Bulletin of the Geological Society of Denmark 41, 203-218.

Knudsen, K.L., Ditlefsen, C., Penney, D.N., Kristensen, P., Kronborg, C. \& Eiríksson, J. 2014: Elsterian-Holsteinian deposits at Kås Hoved, northern Denmark: sediments, foraminifera, ostracods and stable isotopes. Boreas 43, 251-271.

Kronborg, C. \& Odgaard, B.V. 2004. Nyt om Danmarks ældste kvartære aflejringer. DGF kvartærgeologisk møde november 2004. Geologisk Tidsskrift 2004(2), 23-24.

Kronborg, C., Nielsen, O.B., Sørensen, J. \& Kragelund, A. 2002: Ringkøbing Amt, Holstebro Nord, boring DGU Nr. 64.1248. Geologisk Institut, Aarhus Universitet, Report 02RK-01, 39 pp.

\footnotetext{
Authors' addresses

B.V.O. \& K.L.K., Department of Geoscience, Aarhus University, Høegh-Guldbergs Gade 2, DK-8000 Aarhus C, Denmark. E-mail: bvo@geo.au.dk O.B. \& H.J.G., Geological Survey of Denmark and Greenland, Øster Voldgade 10, DK-1350 Copenhagen K, Denmark.
} 